\title{
BEARING CAPACITY OF T-CROSS SECTION PILES IN SAND
}

\author{
Oleg MALYSHEV ${ }^{1}$ \\ Bases and foundations department, Kyiv National University of Construction \\ and Architecture, Kyiv, Ukraine
}

\begin{abstract}
This paper describes a series of pile tests in sand. T-cross and square cross section piles were jacking by static vertical load with a vibration. Special tests were carried out to examine the influence of T-cross section pile form on it bearing capacity, and the results of comparison bearing capacity on one cub meter of T-cross and square cross section jacking piles in the same ground conditions are described. The jacking vertical static load, sizes of displacements and compaction zones of a ground around a shaft of the experienced piles were investigated.
\end{abstract}

Keywords: pile, T-cross section, bearing capacity, field tests, sandy soil, precast concrete, compaction zones, jacking

\section{INTRODUCTION}

The quantity of civil works increases today. The requirement of new sites without buildings grows too. Very often these territories are in negative engineeringgeological conditions. Furthermore the quantity of superstructure increases. That's why we need safety and economic foundations. Such foundations can be piles. Some type of piles are determined as the most widely used in construction practice. Piling technology is provided with high quality equipment and well developed by building companies. These are jacked or driven into the ground concrete piles with square cross section. These piles are also the most used in the construction of buildings and structures in Ukraine. But the relation of piles

1 Corresponding author: Bases and foundations department, Kyiv National University of Construction and Architecture, Ukraine, Kyiv-037, Povitroflotsky Avenue 31, tel. +380968125359 . 
bearing capacity on the ground for one cubic meter of material in most cases is relatively a small value. Thus this pile construction doesn't respond modern requirements of efficiency and economy [7]. In this considerable volume of concrete is spent. Unfortunately there is no final decision as to choice the most effective pile and pile foundation parameters at present time. They depend on the ground conditions of the construction site, and in most cases should be considered and taken into account in each case individually. The main factors affecting the bearing capacity of piles is: cross section and the length of the pile, the quantity of piles in the foundation, the distance between piles, the installation method, manufacturing method, material etc. The correct choice of the form and cross section dimensions allow to use the maximum material strength at the maximum load on a pile at the base of the ground. A similar opinion has Trofimenkov [10]. He proposed for the foundation design on a friction piles to take the maximum cross section perimeter of the pile. This will increase the bearing capacity of the pile on the lateral surface. And research results $[6,7,8,9]$ shows that the change in cross section pile form can improve pile bearing capacity of the ground base in several times. The cross section modification, the use of effective concrete types and introduction of new construction which include T-cross section pile can eliminate these shortcomings and improve the efficiency of piles and pile foundations $[9,11]$.

Bearing capacity of square, round, triangular, T-cross and square cross section driven piles according to the requirements of Ukrainian standards was defined at the first stage of investigations. The obtained results were compared with each other. Based on a comparison for further researches was selected T-cross section as the most effective pile form. Laboratory and field tests and their comparisons for a square and T-cross section pile models were carried out at second and third stage [1]. Field experimental investigations of T-cross section piles and confirmation of laboratory and field research results of pile models were carried out at fourth stage in sands.

\section{GROUND CONDITIONS}

The geological conditions of investigation site are alluvial deposits of the first fluvial terrace r. Siverko. From the ground surface to the depth 2,5 m there are medium density fine sands, low degree of saturation. Below them are water saturated medium density fine sands of a thickness $0,4 \mathrm{~m}$. Below are water saturated dense fine sands. Ground conditions of the investigated site and values of ground properties are similar to the base which was used in the laboratory researches on the second stage (Fig. 1). 


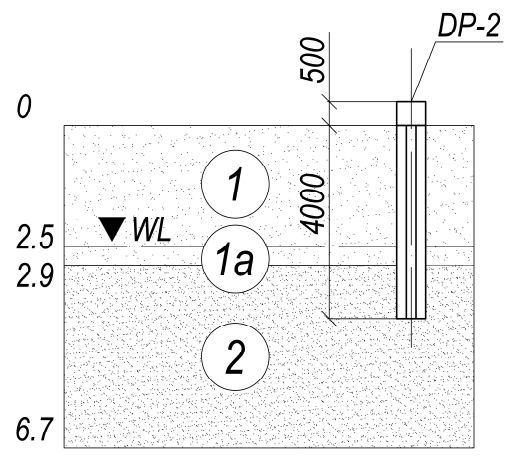

Medium density fine sands, low degree of saturation $\left(\mathrm{E}=15 \mathrm{MPa}, \varphi_{\mathrm{II}}=31^{\circ}, \mathrm{c}_{\mathrm{II}}=2 \mathrm{kPa}\right)$ and water saturated sands $\left(\mathrm{E}=13 \mathrm{MPa}, \varphi_{\mathrm{II}}=30^{\circ}\right.$, $\left.\mathrm{c}_{\mathrm{II}}=1 \mathrm{kPa}\right)$

Water saturated dense fine sands $(E=30 \mathrm{M \Pi а}$, $\left.\varphi_{\mathrm{II}}=36^{\circ}, \mathrm{c}_{\mathrm{II}}=4 \mathrm{kPa}\right)$

Fig. 1. Geological conditions, ground properties of investigation site and location of experienced pile

\section{MATERIALS, EQUIPMENTS, FIELD TESTS}

Four T-cross section (DP-1... DP-4) and one square pile (DP-5) were used as experienced. The material of piles was concrete $(\mathrm{C} 25 / 30)$. All piles were made of $4,5 \mathrm{~m}$ long. The side of square cross section pile has a size of $300 \mathrm{~mm}$. Specifications of T-cross section pile are sown in Fig. 2.
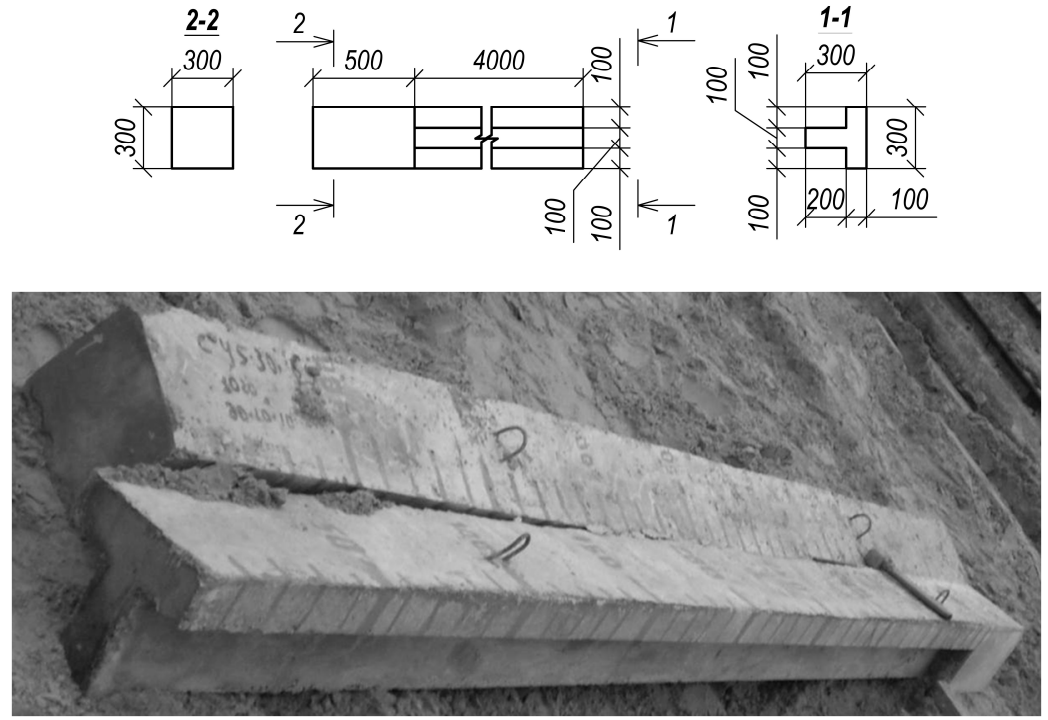

Fig. 2. Specifications of precast concrete T-cross section pile

All piles were made on a scale of 5:1 in comparison with the models that were used in the second and third stage of the research. The piles were jacked under 
the axial vertical static load. To minimize compressive stresses, simplify installation conditions and field tests the top part of T-cross section piles has a square form of $500 \mathrm{~mm}$ long.

Piles were jacked down into the ground by using the installation platform PV-1. Piles location scheme in plan is shown in Fig. 3. All piles were jacked without the help of leader boreholes from the site surface. Jacking load speed was 0,5 meters per minute. The piles were jacked down for the two approaches. The rest between sets time was one day.

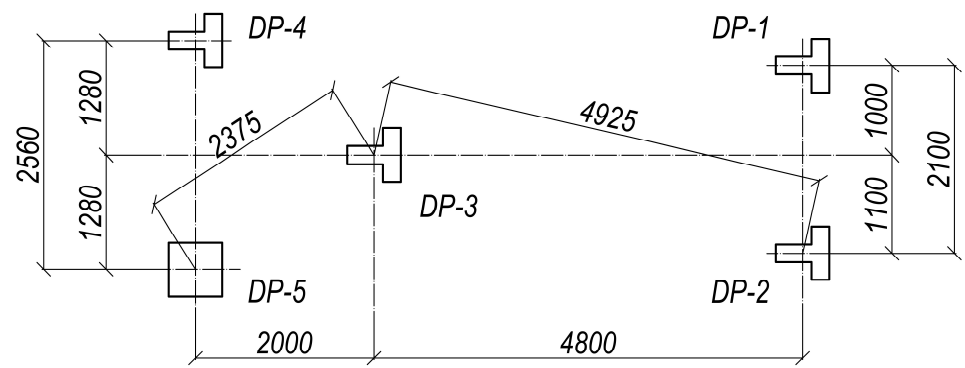

Fig. 3. Piles location scheme

Construction experience in similar soil conditions shows the impossibility to install square cross section pile to a given depth. This is due with a dense sands that are lies under the pile toe, and not enough load pressing value of the installation platform PV-1. Therefore a induction vibrator motor was used to reduce jacking stress and improve the quality of a base. Two piles (DP-4 and DP5) were installed with its help to a depth of $4 \mathrm{~m}$. Piles DP-1, DP-2 and DP-3 were installed to a depth of 3,5;4,0;3,5 $\mathrm{m}$ respectively. The base of piles DP-2 and DP-3 was improved by the action of vibration during the time period of 4-5 min. Relative penetration value of piles are 11,7-13,3, which is coordinated with the laboratory tests. Jacking load was controlled for each pile.

Load tests were carried out in according to requirements of Ukrainian standards [5] three days after piling. Vertical load on the pile was applied by a DG 200-2 hydraulic jack. VP-1 jacking installation platform type was a support of a jack. Pile movements were fixed by using a hour type 6PAO sensors. Static vertical load was applied to the pile top in steps of $70 \mathrm{kN}$. For conditional deformation criterion stabilization was taken the speed of the settlement at the given stage which does not exceed $0,1 \mathrm{~mm}$ in the last 60 minutes during the tests. Unloading was carried out in steps of $140 \mathrm{kN}$ with a delay of 15 minutes.

\section{THE RESULTS OF FIELD TESTS}

Previously bearing capacity of piles can be defined by their jacking force. Therefore, the jacking force and diving depth has received considerable attention. 
The dependence of the jacking force $(\mathrm{P}, \mathrm{kN})$ from the pile installation depth $(\mathrm{H}, \mathrm{m})$ is shown in Fig. 4. Plots shows that the use of T-cross section piles allow to install them without the help of leader boreholes to a depth of 3,5-4,0 m. Required for install of T-cross section pile vertical jacking force was reduced by $20 \%$ in comparison with a square pile. The use of a vibrator motor can reduce the jacking force from 1200 to $950 \mathrm{kN}$, scilicet in 1,26 times.

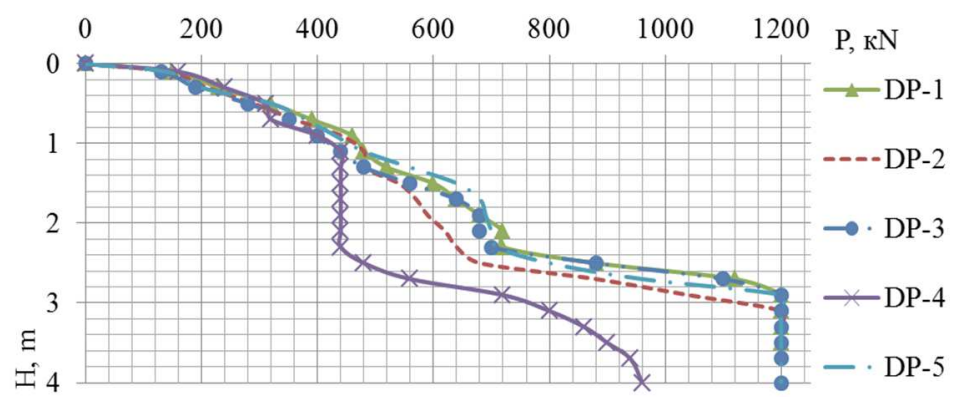

Fig. 4. The dependence of the jacking force $(\mathrm{P}, \mathrm{kN})$ from the pile installation depth $(\mathrm{H}, \mathrm{m})$

Processing of test results was carried out by the end of the experience and depending plots of settlement from the load $(S=f(P))$ were created. Dependence of the settlement on the load plots for the T-cross section piles DP-1 and DP-4 have a deviation up to 5\%. A vibrator motor use during jacked down almost no increase piles bearing capacity but makes it possible to facilitate their installation in the dense sands. This shows an opportunity of comparing the results of T-cross section pile field tests with a square pile DP-5.

In all load ranges bearing capacity of square pile is higher than bearing capacity of T-cross section pile. So for the DP-1 and DP-4 this excess is up to $15 \%$, and for DP-2 and DP-3 is up to $6 \%$ on average. For correct comparison of different pile types is necessary to determine the material efficiency coefficient $K$ which is called the specific bearing capacity. It is equal to the ratio of bearing capacity on the one cubic meter of the pile material. Dependings from the settlement of the specific bearing capacity (coefficient $K$ ) and their comparisons are shown in graph form (Fig. 5). The specific load-bearing capacity of piles DP-1, DP-2 is $45 \mathrm{kN} / \mathrm{m} 3$, for DP-3, DP-4, DP-5 pile is 50,$91 ; 39,85 ; 26,2 \mathrm{kN} / \mathrm{m} 3$ respectively. The coefficients $K$ ratio for the T-cross and square cross section pile form were also determined and shown in Fig 5. It is equal to $75 \%$ for PD-1/PD-5, DP-2/DP-5 ratio, $101 \%$ for DP-3/DP-5 ratio and $56 \%$ for DP-4/DP-5 ratio, and shows a considerable performance and efficiency of T-cross section in comparison with a square cross section pile form. 


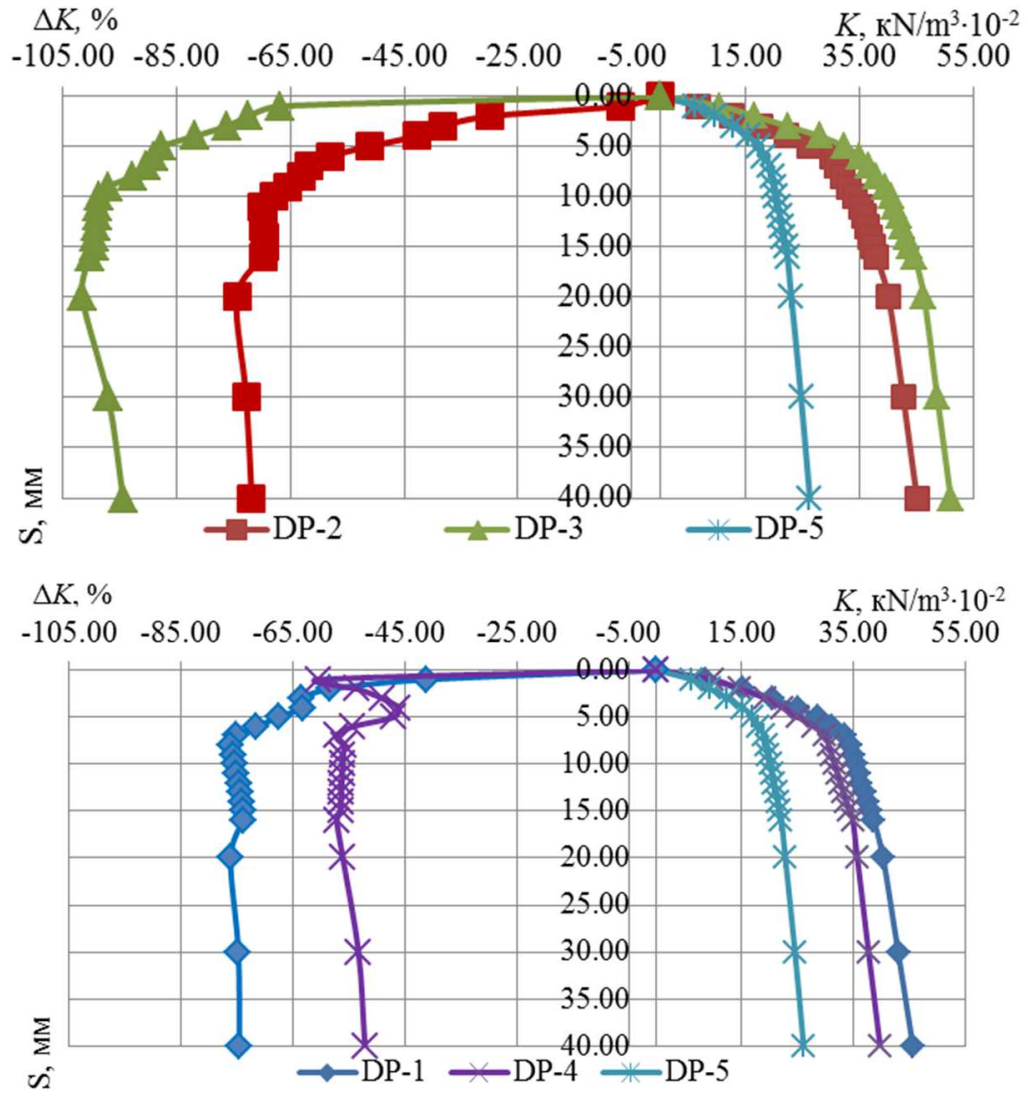

Fig. 5. The dependence of the coefficient $K$ from the settlement

\section{GROUND BASE INVESTIGATION}

The difference in the bearing and specific bearing capacity of T-cross section and square piles is explained by their different lateral surface ground base work. Some researchers guess that the piles with a developed cross section form are attracted to work a certain mass of soil that is formed between the pile blades during installation $[2,3,4,12]$. In order to examine the changes that occur in the soil base during piling dynamic probing tests were carried out around experienced piles (Fig. 6).

For a better perception dynamic probing tests graphics shown for the first and last points in Fig.7. Further for a more completed and detailed research the excavation of experienced piles were carried out. Density changes of the soil around the lateral surface of the piles every $10-15 \mathrm{~cm}$ by depth within a probing points were determined by the cutting ring and CPT method for its further research and 
determination dry density of the soil. Soil density determined in vertical and horizontal directions. The sand layers with a different colors were discovered after the digging of experienced piles and shown in Fig. 8. With their help were fixed lines of ground displacements around the lateral surface of experienced piles. For a detailed study of the ground displacements areas the digging on sections shown in Fig. 9 was carried out. The investigations which took place have established the size of compaction zones of a ground around experienced piles.

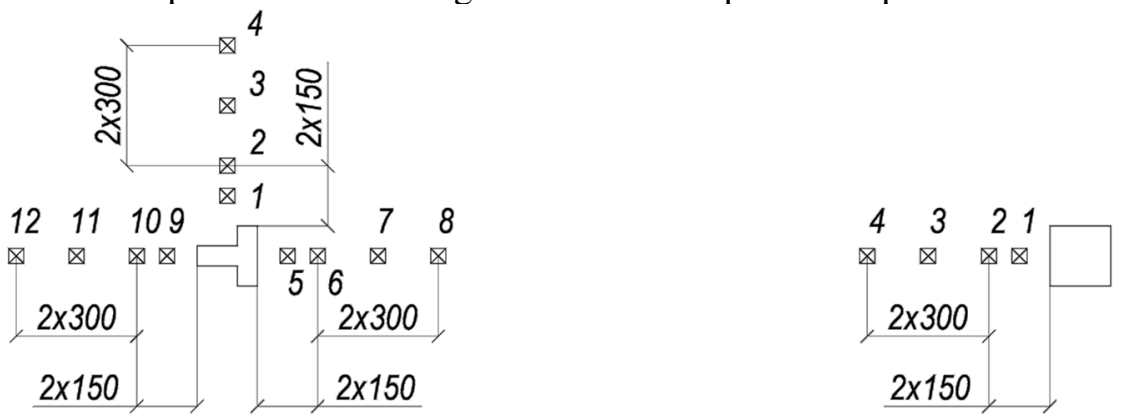

Fig. 6. DPT points around experienced piles

Number of blows, $n$, at deepening on $10 \mathrm{~cm}$

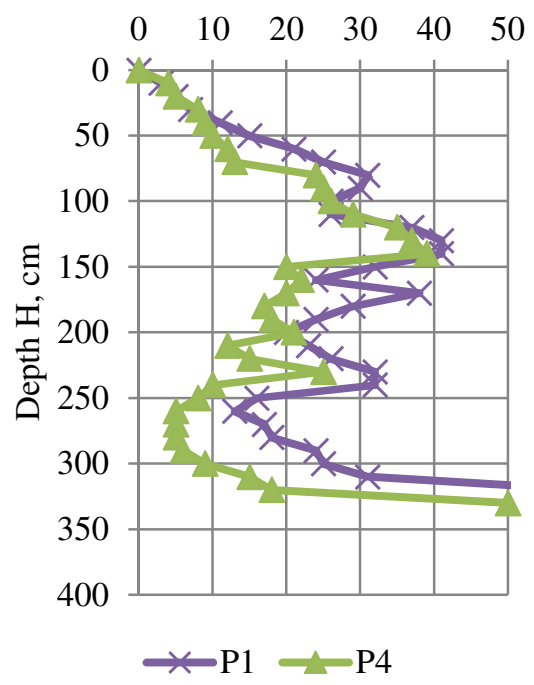

Number of blows, $n$, at deepening on $10 \mathrm{~cm}$

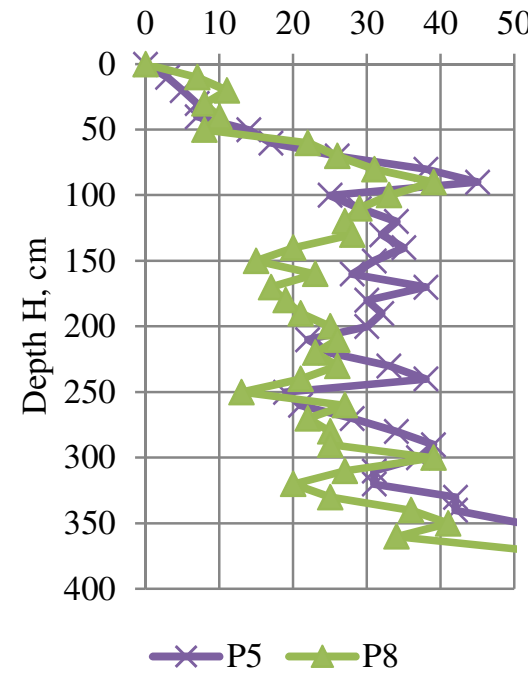



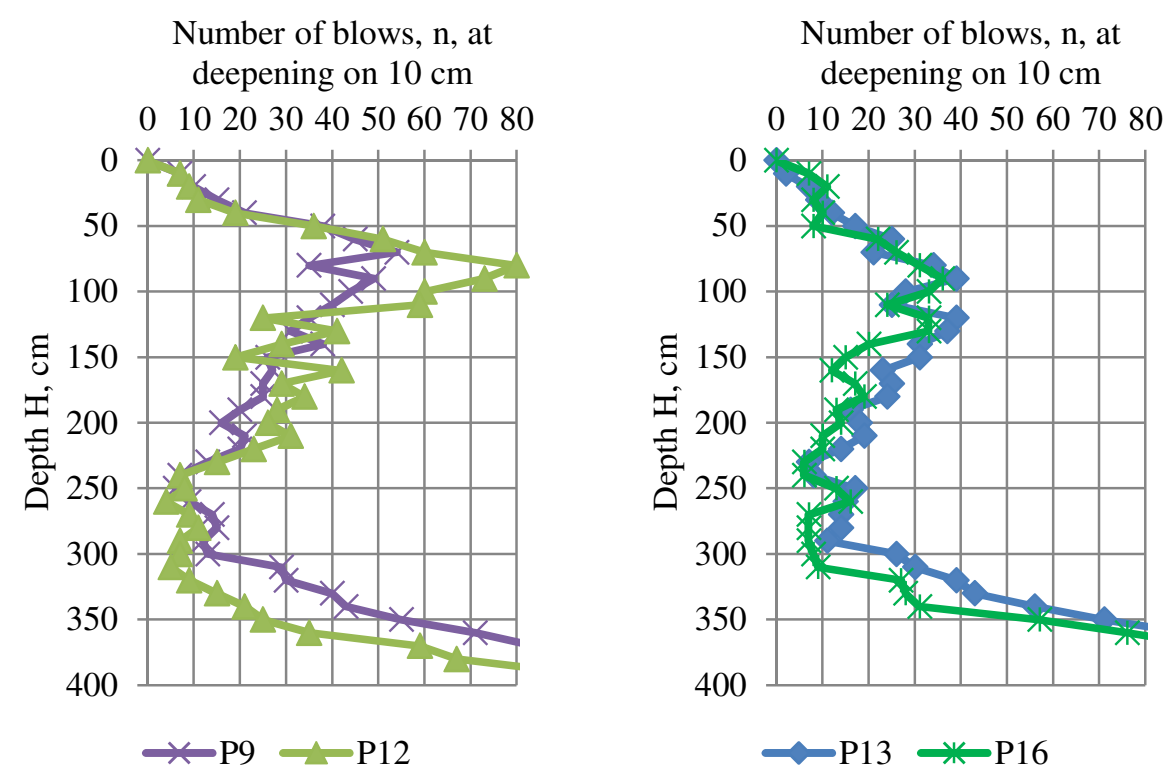

Fig. 7. The number of blows on the depth depending graphics

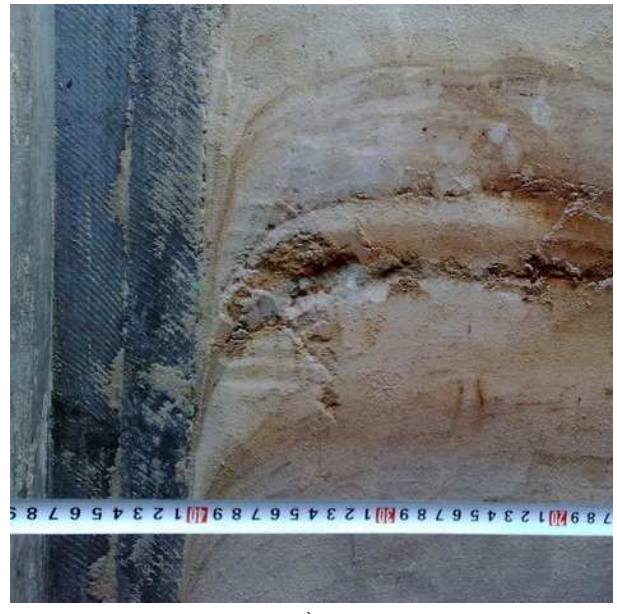

a)

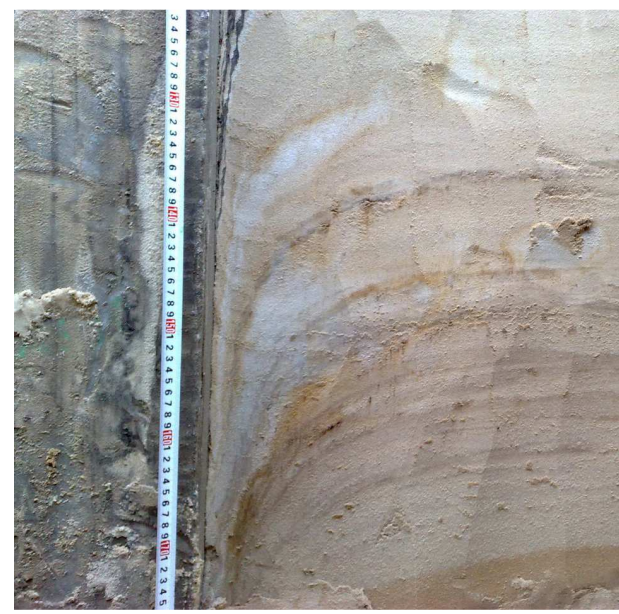

b)

Fig. 8. Lines of ground displacements around the lateral surface of T-cross section (a) and square (b) piles

For T-cross section pile from the cross section center of gravity in the horizontal direction compaction zones of a ground are equal to: for shelf $1,28 \mathrm{D}$, for an edge - 1,29 D, left and right from the edges - 1,03 D. The average 
radius of the ground area move around the T-cross section pile from the center of the pile and it is $1,035 \mathrm{D}$, and the compaction area and it is $1,16 \mathrm{D}$. The average radius of the ground area displacements around the square cross section pile from the center of the pile and it is 1,27 D, and the compaction area and it is 1,6 D. D is equal to the square pile side size $(300 \mathrm{~mm})$.<smiles>[3H]C1CCCCC1C1CCCCC1</smiles><smiles>CC1CCCCC1</smiles>

$\mathrm{K}_{4}$

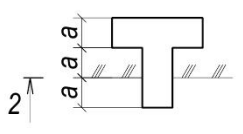

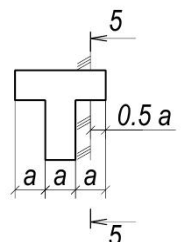<smiles>[Y][I-]</smiles><smiles>CC1CCCCC1</smiles>

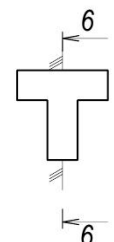

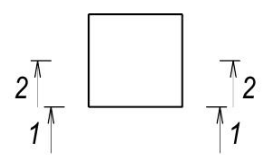

Fig. 9. Section where the digging of the piles were carried out
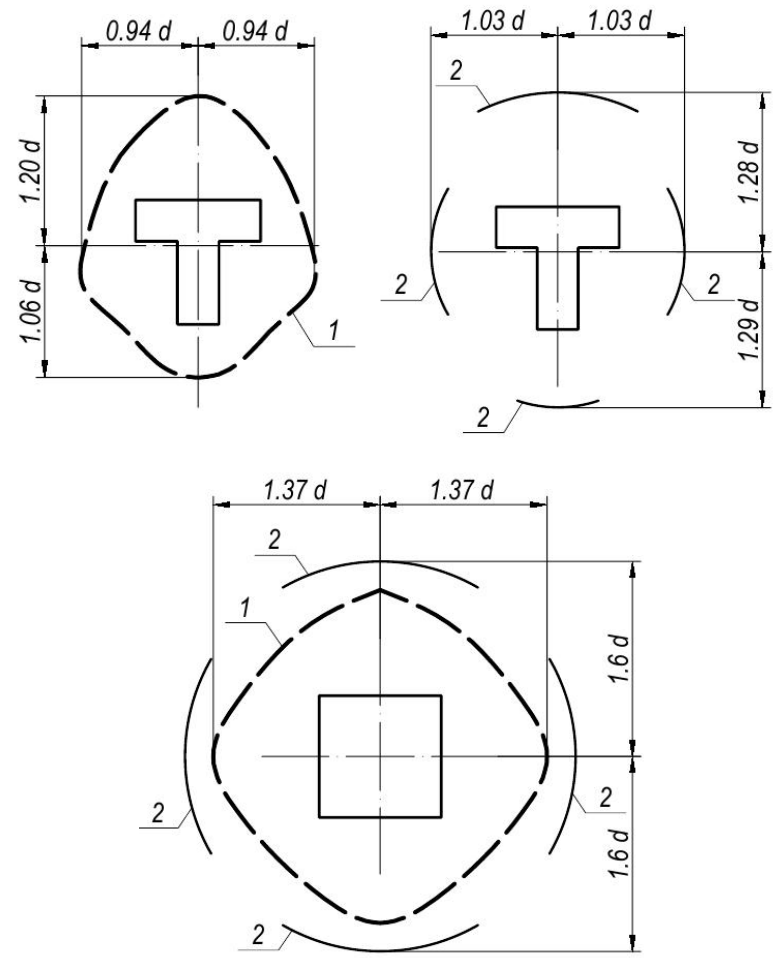

Fig. 10. Displacement (1) and compaction (2) zones of a ground around experienced piles 
Dry density of the ground around experienced piles varied from the natural values of $1,59 \mathrm{gr} / \mathrm{cm}^{3}$ to $1,65 \mathrm{gr} / \mathrm{cm}^{3}$ for square piles; to $1,67 \mathrm{gr} / \mathrm{cm}^{3}$, from the right and left side of the T-pile edge, 1,66 gr/ $\mathrm{cm}^{3}$ after the shelf and $1,63 \mathrm{gr} / \mathrm{cm}^{3}$ in front of the edge. Experienced piles were digged and taken out at the end of the research. Compacted soil zone along the length of the T-pile between the shelf and the edge was recorded after it removing from the ground. An equilateral triangle shape it had.

The volume of ground displacements by the square pile during piling is larger then the volume of ground displacements by the T-cross section pile. Because of that the dimensions of compaction areas of a ground around a lateral surface of the square cross section pile are also larger. The maximum compaction value of a ground was fixed in the lateral surface of T-cross section pile between the shelf and edge in a comparison with a square pile. This area takes part on the lateral surface and the tip pile work. Therefore, the work of the T-pile on a ground base is change and increase its specific load bearing capacity.

\section{CONCLUSIONS}

1. It has been found that the specific bearing capacity of the T-cross section pile on $56-75 \%$ higher than the specific bearing capacity of square pile. It occurs due to the changes in cross section pile form.

2. The comparison of pile jacked down force from the depth shows high performance of T-pile up to 1,2 times over square pile.

3. The use of a vibration motor in the seal mode allows to increase specific bearing capacity of T-cross section piles up to $102 \%$ in comparison with the square pile.

4. On the lateral surface of T-piles high compaction zone was detected. This zone participates in the pile ground base work.

5. The value of the ground base displacement and compaction radius around the lateral surface of the T-cross and square cross section piles was determined.

6. Displacement and compaction zones of a ground around cross section of experienced piles were constructed. They allow to analyze the character of the stress distribution in the piles ground base, which occur during their pilling and working. This allows to develop or improve the existing methods of the piles calculations.

7. Reducing the material consumption, labour costs and increasing the efficiency of pile foundations are possible by using T-cross section piles. 


\section{REFERENCES}

1. Cimbal, S.J., Malishev, O.V.: Eksperimental'ni laboratorni doslidzhennja pal' z rozvinutoju bichnoju poverhneju, Osnovi ta fundamenti, 32 (2011) 95-101.

2. Code for the design and calculation of civil engineering foundations. Fascicule 62, Tire V of the CCTG, 1993.

3. De Beer E.E.: Amelioration de la capacite portante de pieux metalliques HP (Improvement of the carrying capacity of HP steel piles). Annales des travaux publics de belgique, 6 (1989).

4. De Beer E. E., Weber L.: Belglan geotechnical volume published for the 1985 golden jubilee of the international society for soil mechanics and foundation engineering. Leuven, Ceuterick, 9-25.

5. DSTU B V.2.1-1-95. Grunti. Metodi pol'ovih viprobuvan' paljami. Kiïv, Ukrarhbudinform, 1997.

6. Kravtsov V.N.: Zabivnyie svai ratsionalnogo poperechnogo secheniya. 300-307.

7. Lobov, O.I.: Jeksperimental'naja proverka nesushhej sposobnosti zabivnyh svaj razlichnoj formy, Issledovanie raboty osnovanij i fundamentov promyshlennyh zdanij i sooruzhenij, 22 (1969) 153-161.

8. Lobov O.I.: $O$ ratsionalnyih formah zabivnyih svay $(v$ poryadke predlozheniya), Issledovanie rabotyi osnovaniy i fundamentov promyishlennyih zdaniy i sooruzheniy: sbornik trudov, Sverdlovsk, Sverdlovskiy PromstroyNIIproekt, 22 (1969) 144-152.

9. Tetior, A.N.: Progressivnye konstrukcii fundamentov dlja uslovij Urala i Tjumenskoj oblasti, Sverdlovsk 1971.

10. Trofimenkov Yu.G., Obodovskiy A.A.: Svaynyie fundamentyi dlya zhilyih i promyishlennyih zdaniy, Moscow, Stroyizdat 1970.

11. Voort, T. V.: Design and performance verification of UHPC piles for deep foundations, Iowa State University 2008.

12. Yaresko V.F.: Progressivnyie tonkostennyie shirokolopastnyie svai, Perm 1965.

\section{NOŚNOŚĆ PALI O PRZEKROJU TEOWYM W PIASKACH}

\section{Streszczenie}

W artykule opisano serię testów pali w glebach piaszczystych. Pale o przekroju teowym i kwadratowego były obciążane pionową siłą statyczną z wibracją. W badaniach testowano wpływ formy teowych pali na ich nośność, oraz opisano rezultaty porównania nośności 
w przeliczeniu na metr sześcienny betonu użytego do wykonania pali przekroju teowym i kwadratowym. Mierzono wartość siły wbijającej, przemieszczenia pala i zagęszczenie gruntu przy trzonie badanych pali.

Słowa kluczowe: pal, przekrój teowy, nośność, badania polowe, gleby piaszczyste

Editor received the manuscript: 10.07.2017 